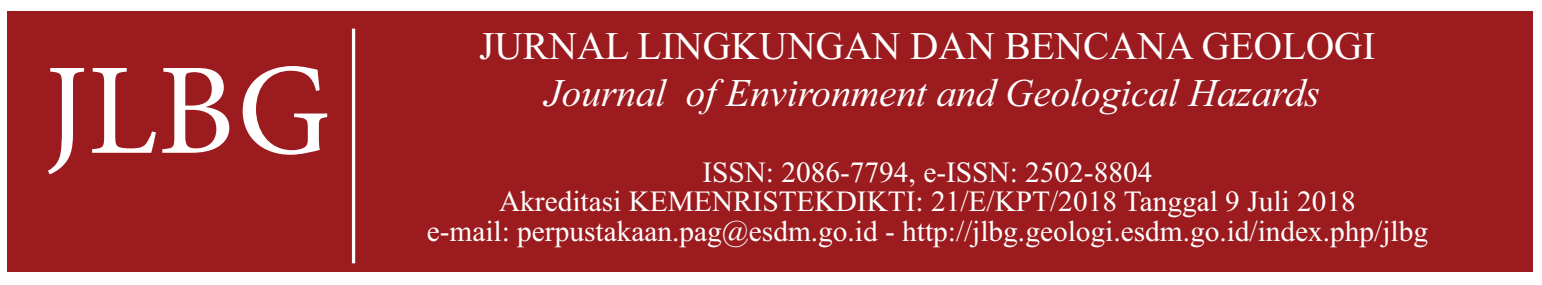

\title{
Bencana Kekeringan di Wilayah Taman Bumi Nasional Karangsambung-Karangbolong: Pengontrol, Dampak, dan Ketahanan
}

\author{
Drought Disaster in Karangsambung-Karangbolong National Geopark Area: \\ Controllers, Impact, and Resilience
}

\author{
Sugeng Purwo Saputro ${ }^{1, *}$, Dwi Ratih Purwaningsih ${ }^{2}$, dan Rahmi Mulyasari ${ }^{3}$ \\ ${ }^{1}$ Pusat Penelitian Geoteknologi (LIPI) \\ Jl. Sangkuriang, Bandung, 40135, Indonesia \\ ${ }^{2}$ Program Studi Kimia, Fakultas Matematika dan Ilmu Pengetahuan Alam (FMIPA)-ITB \\ Jl. Ganesha No. 10, Bandung, 40132, Indonesia \\ ${ }^{3}$ Program Studi Teknik Geofisika, Fakultas Teknik (FT)-Unila \\ Jl. Prof. Dr. Sumantri Brojonegoro No. 1, Bandar Lampung, 35145, Indonesia \\ e-mail: sugeng.purwo.saputro@lipi.go.id \\ Naskah diterima 17 April 2020, selesai direvisi 20 April 2021, dan disetujui 30 April 2021
}

\begin{abstract}
ABSTRAK
Karanggayam dan Karangsambung di Kabupaten Kebumen termasuk ke dalam zona bahaya tinggi terdampak bencana kekeringan. Kedua daerah tersebut memiliki variasi batuan yang lengkap mulai dari batuan beku, batuan sedimen, hingga batuan metamorf, dan termasuk ke dalam wilayah Taman Bumi Nasional Karangsambung-Karangbolong. Prediksi dan penentuan area yang masih memiliki cadangan air tanah menjadi hal yang vital untuk segera dilakukan guna mengurangi dampak dari bencana tersebut, ditunjang dengan pengetahuan mengenai pengontrol utama dari parameter penyebab bencana kekeringan di daerah Karanggayam dan Karangsambung. Observasi lapangan dan analisis geospasial dipilih menjadi metode karena dinilai lebih efisien untuk penelitian ini, serta didukung dengan hasil analisis statistik dari data sekunder. Fisiognomi tanah, kondisi geologi, dan angka infiltrasi yang merupakan bagian dari delapan karakteristik geografi dan geomorfologi, dinilai menjadi pengontrol utama dari parameter penyebab bencana kekeringan yang terjadi di Karanggayam dan Karangsambung. Ketiga karakteristik tersebut berperan dalam mempersempit kemungkinan area cadangan air tanah menjadi hanya berada di sekitar lembah antiklin dan lereng sayap antiklin bagian selatan-tenggara (S-SE). Seluruh hasil penelitian ini dapat berfungsi untuk membantu pemerintah daerah dan pengelola taman bumi dalam membuat berbagai macam perencanaan dan kebijakan terkait Taman Bumi Nasional Karangsambung-Karangbolong.
\end{abstract}

Kata kunci: bencana, cadangan air tanah, Kebumen, kekeringan, taman bumi

\begin{abstract}
Karanggayam and Karangsambung in Kebumen Regency included in the high danger zone affected by drought. Both areas have complete rock variations ranging from igneous, sedimentary, to metamorphic rocks, and are included in the Karangsambung-Karangbolong National Geopark. Prediction and determination of areas that still have groundwater reserves are vital to be carried out immediately to reduce the disaster's impact, supported by the knowledge of the main controllers of drought-causing parameters in the both areas. Field observations and geospatial analysis were chosen because they were considered more efficient and supported by the results of statistical analysis from secondary data. Soil physiognomy, geological conditions, and infiltration rates are considered the main controllers causing drought disasters in Karanggayam and Karangsambung areas. These three characteristics narrow down the possibility that the groundwater reserve area is only around the anticline valley and the south-southeast (S-SE) side of the anticline wing. All of the result of this study can help local governments and geopark management to make various plans and policies related to the Karangsambung-Karangbolong National Geopark.
\end{abstract}

Keywords: disaster, groundwater reserves, Kebumen, drought, geopark 


\section{PENDAHULUAN}

Kekeringan merupakan kejadian hilang/kurangnya kuantitas air tanah untuk sementara waktu, disebabkan oleh curah hujan yang secara signifikan berada di bawah normal (Hund drr., 2018; van Loon dan Laaha, 2015). Kejadian tersebut jika sampai mengganggu rutinitas kehidupan manusia, dapat dikategorikan sebagai bencana (Liu drr., 2019). Kriteria bencana kekeringan totalnya ada 17 jenis, sebagai turunan dari empat kriteria utama; di antaranya meteorologi, pertanian, hidrologi-hidrogeologi, dan sosialekonomi (Hao drr., 2016; Hoque drr., 2020; van Loon dan Laaha, 2015). Hidrologi-hidrogeologi merupakan kriteria yang paling mempengaruhi terjadinya bencana kekeringan dibandingkan kriteria utama lainnya, karena jangkauannya yang luas serta dikontrol oleh banyak parameter. Bencana kekeringan diperhitungkan sebagai salah satu bencana alam yang sangat merusak dibandingkan bencana alam lainnya, khususnya dalam hal ekonomi/biaya, masalah sosial, dan dampak ekologi (Hao drr., 2016; van Loon dan Laaha, 2015). Penilaian tersebut didasarkan pada dampak bencana yang luas, durasi yang lama dan perkembangan lambat, serta berdampak langsung pada kehidupan manusia (Yang drr., 2016). Masalah-masalah tersebut muncul karena ekosistem dan sosial masyarakat bergantung pada air yang berasal dari zona tangkapan air (catchment area), seperti akuifer, danau, dan sungai, dibandingkan dari hasil presipitasi langsung. Saputro dan Mulyasari (2020) berpendapat bahwa proses infiltrasi dan perkolasi yang terhambat merupakan faktor utama penyebab terjadinya bencana kekeringan (Tabel 1). Parameter penghambatnya dikontrol oleh karakteristik geografi dan geomorfologi, ni- lai besaran permeabilitas, porositas, dan tekanan, serta proses disolusi, sementasi, dan kompaksi (Saputro dan Mulyasari, 2020).

Daerah Karanggayam dan Karangsambung yang merupakan bagian dari wilayah taman bumi nasional (national geopark) termasuk dalam zona bahaya tinggi terdampak bencana kekeringan (Saputro dan Mulyasari, 2020). Hal tersebut merupakan suatu anomali jika dibandingkan dengan daerah sekitarnya di Kabupaten Kebumen (Tabel 1 dan Gambar 1). Pavlova drr. (2017) berpendapat bahwa warisan dunia UNESCO maupun nasional sebagian besar tidak terlindungi dari bahaya bahkan bencana geologi, yang seharusnya menjadi hal sangat

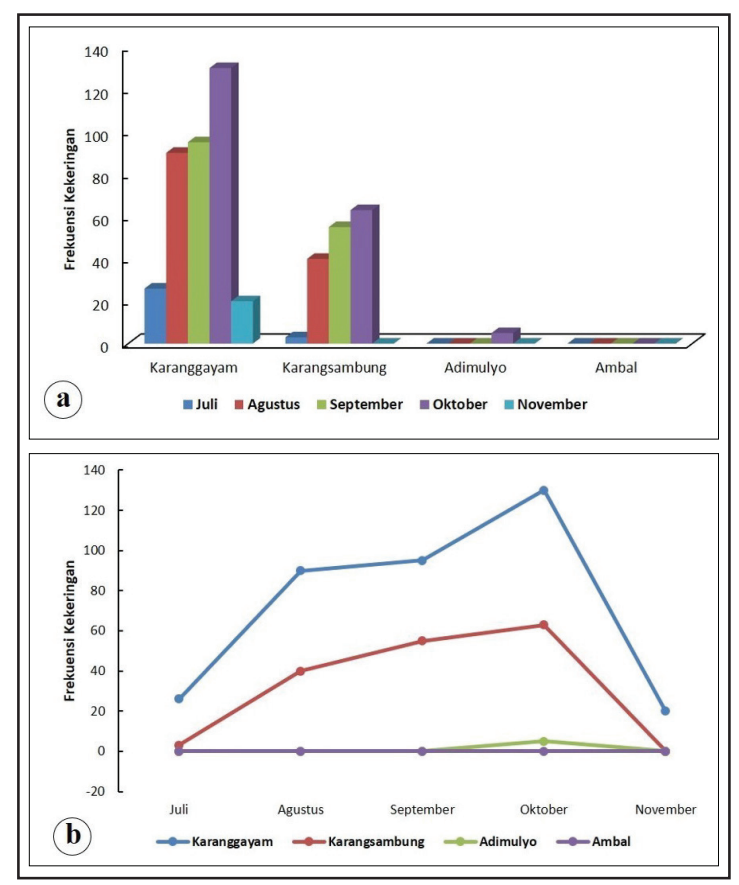

Gambar 1. (a) Perbandingan frekuensi dan (b) fluktuasi frekuensi bencana kekeringan pada masing-masing kecamatan di Kabupaten Kebumen dalam kurun waktu lima bulan (Saputro dan Mulyasari, 2020).

Tabel 1. Lokasi dan frekuensi bencana kekeringan di Kabupaten Kebumen (Saputro dan Mulyasari, 2020).

\begin{tabular}{|c|c|c|c|c|c|c|c|c|c|}
\hline \multirow{2}{*}{ No. } & \multirow{2}{*}{ Kecamatan } & \multicolumn{5}{|c|}{ Frekuensi Kekeringan / Bulan } & \multicolumn{2}{|c|}{ Jumlah Desa } & \multirow{2}{*}{$\begin{array}{c}\text { Frekuensi } \\
\text { Kekeringan } \\
\text { (Juli-November } \\
\text { 2018) }\end{array}$} \\
\hline & & Juli & Agustus & September & Oktober & November & Total & Kekeringan & \\
\hline 1 & Karanggayam & 26 & 90 & 95 & 130 & 20 & 19 & 8 & 361 \\
\hline 2 & Karangsambung & 3 & 40 & 55 & 63 & 0 & 14 & 5 & 161 \\
\hline 3 & Adimulyo & 0 & 0 & 0 & 5 & 0 & 23 & 1 & 5 \\
\hline 4 & Ambal & 0 & 0 & 0 & 0 & 0 & 32 & 0 & 0 \\
\hline
\end{tabular}


penting untuk dianalisis dengan cermat guna menilai seberapa besar risiko bencana tersebut.

Penelitian ini bertujuan untuk mengetahui karakteristik geografi dan geomorfologi yang paling bertanggung jawab terhadap bencana kekeringan di daerah Karanggayam dan Karangsambung, serta untuk mengetahui area yang masih memiliki cadangan air tanah. Tujuan tersebut dicapai dengan penekanan pada aspek petrologi dan lingkungan, serta hidrogeologi terkait proses infiltrasi dan perkolasi. Evaluasi terhadap karakteristik geografi dan geomorfologi merupakan langkah kunci untuk mendeteksi area potensi cadangan air tanah, karena memiliki akurasi yang tinggi dan mampu meminimalisir kesalahan penafsiran (Etikala drr., 2019; Jenifer dan Jha, 2017; Mishra drr., 2019).

\section{METODE PENELITIAN}

Lokasi penelitian berada di Kecamatan Karanggayam dan Karangsambung, Kabupaten Kebu- men, Jawa Tengah (Gambar 2). Objek penelitian berupa morfologi dan batuan yang termasuk ke dalam (urut tua ke muda) Kompleks Lok Ulo (KTl), Formasi Karangsambung (Teok), Formasi Totogan (Tomt), Anggota Tuf Formasi Waturanda (Tmwt), Formasi Waturanda (Tmw), dan Formasi Penosogan (Tmp). Pendekatan yang digunakan untuk mencapai tujuan penelitian meliputi observasi lapangan dan analisis geospasial, dengan dukungan hasil analisis statistik dari data sekunder (Gambar 1).

Observasi lapangan dan analisis geospasial yang umumnya bersifat kualitatif menjadi kegiatan yang pertama kali dilakukan dalam penelitian ini. Selain untuk mendapatkan data lapangan terbaru dan percontoh batuan, juga untuk mendapatkan gambaran umum secara keseluruhan. Selanjutnya data hasil observasi lapangan dan analisis geospasial dikompilasi dengan data hasil analisis statistik yang lebih bersifat kuantitatif, sehingga didapatkan data yang berkualitas. Analisis geospasial dipilih

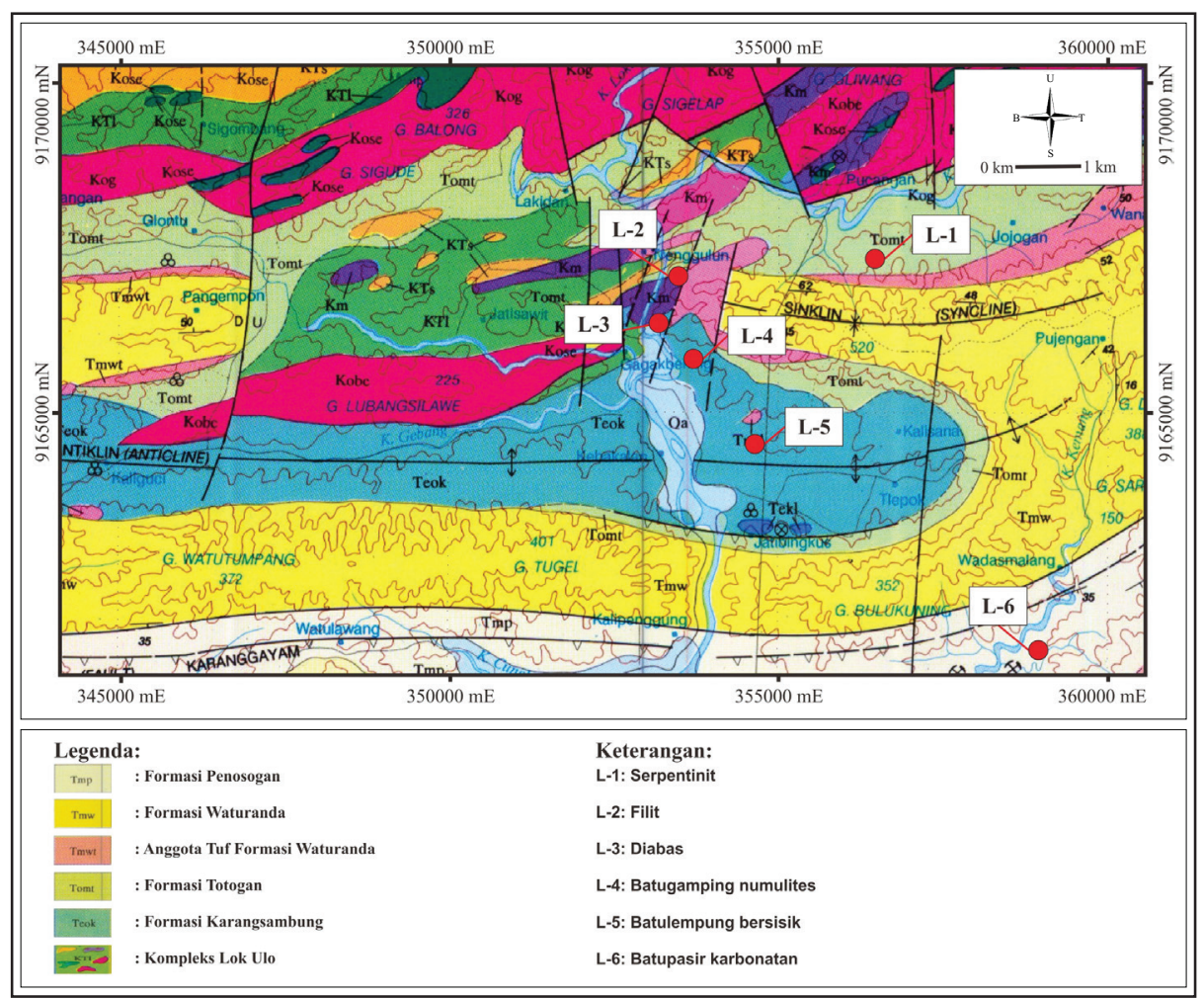

Gambar 2. Peta geologi daerah Karanggayam dan Karangsambung, serta titik lokasi pengambilan percontoh batuan (modifikasi dari Asikin drr., 1992). 
menjadi salah satu pendekatan karena dinilai lebih efisien untuk menguraikan potensi air tanah, serta dapat menghemat waktu dan tenaga (Etikala drr., 2019). Analisis geospasial juga memiliki keunggulan dalam hal mengkombinasikan antara data primer dan sekunder dalam suatu penelitian (Etikala drr., 2019).

Keluaran dari hasil pendekatan-pendekatan tersebut di antaranya deskripsi batuan dan beberapa macam peta pendukung, seperti peta topografi 2D dan 3D. Keluaran tersebut berguna untuk mengetahui karakteristik geografi dan geomorfologi yang paling bertanggung jawab terhadap terjadinya bencana kekeringan di daerah Karanggayam dan Karangsambung, serta untuk menentukan area yang masih memiliki potensi cadangan air tanah.

\section{HASIL DAN PEMBAHASAN}

Tanah di daerah Karanggayam dan Karangsambung memiliki warna cokelat kemerahancokelat keputihan dengan butiran beragam berukuran pasir kasar-lempung, serta berbentuk menyudut-membulat dan terpilah dengan buruk (Gambar 3.a dan 3.b). Warna cokelat kemerahan menunjukkan bahwa tanah tersebut berasal dari pelapukan batuan yang memiliki kandungan besi $(\mathrm{Fe})$ cukup dominan, sedangkan warna cokelat keputihan menunjukkan bahwa komposisi batuan asalnya didominasi oleh mineral karbonat (Asikin drr., 1992; Mul drr., 2007; Saputro dan Mulyasari, 2020).

Ukuran dan bentuk butir yang beragam serta pemilahan yang buruk membuat tanah tersebut memiliki sedikit ruang antar butir, sehingga porositasnya termasuk buruk. Tebal singkapan bervariasi antara 0,05-2,00 meter (m), dengan rincian; lokasi 1-3 memiliki ketebalan antara 0,05-1,50 m, dan lokasi 4-6 antara 0,50-2,00 m (Gambar 2). Perbedaan ketebalan tersebut disebabkan oleh perbedaan tingkat resistansi batuan asal terhadap proses pelapukan. Hal tersebut menunjukkan bahwa fisiognomi tanah di daerah Karanggayam dan Karangsambung secara keseluruhan termasuk buruk. Fisiognomi tanah yang buruk tersebut menyebabkan sulit terjaganya tingkat kelembaban tanah, yang merupakan variabel tepat dan langsung (direct variables) untuk mencerminkan kondisi tanah (Mao drr., 2017). Tingkat kelembaban tanah yang sulit terjaga tersebut menyebabkan terjadinya fluktuasi respon air permukaan untuk mengalami infiltrasi dan perkolasi menuju akuifer (Etikala drr., 2019; Han drr., 2019), sehingga proses pengisian air tanah (recharge) menjadi terganggu dan tidak maksimal (Raju drr., 2019).

Perbukitan merupakan morfologi yang mendominasi daerah Karanggayam dan Karangsambung, dengan persentase mencapai hampir $80 \%$ dari keseluruhan wilayahnya (Gambar 4). Karakteristik perbukitan tersebut terbagi menjadi dua kelompok, yaitu perbukitan yang tersusun oleh bukit-bukit tinggi dan terjal dengan tingkat kerapatan vegetasi sedang dan ketinggian vegetasi antara 1,00-2,50 m, serta perbukitan yang terdiri dari beberapa bukit rendah dan landai dengan kerapatan vegetasi tinggi dan ketinggian vegetasi $>2,50 \mathrm{~m}$ (Gambar 3.c dan 3.d). Perbedaan karakteristik kedua kelompok tersebut berkaitan erat dengan batuan penyusunnya serta peran dari proses geologi di sekitarnya. Batuan keras seperti batuan beku dan metamorf, serta batuan sedimen yang membentuk lipatan (fold) ataupun tersesarkan (fault) menjadi penyusun utama dari bukit-bukit tinggi dan terjal. Sedangkan bukitbukit rendah dan landai sebagian besar disusun oleh batuan sedimen dengan resistansi rendah/ mudah rapuh (Gambar 2). Perkembangan bukitbukit tinggi dan terjal tersebut tidak lepas dari aktivitas tektonik yang terjadi selama periode pembentukan batuan pada umur Pra-Tersier hingga Kuarter.

Dominasi morfologi dengan karakteristik tersebut membuat kemampuan infiltrasi air permukaan menjadi sangat rendah. Hal itu sangat sesuai dengan pendapat Etikala drr. (2019) yang menyatakan bahwa morfologi memberikan pengaruh besar terhadap kejadian geologi, infiltrasi, perkolasi, dan kondisi bawah permukaan 


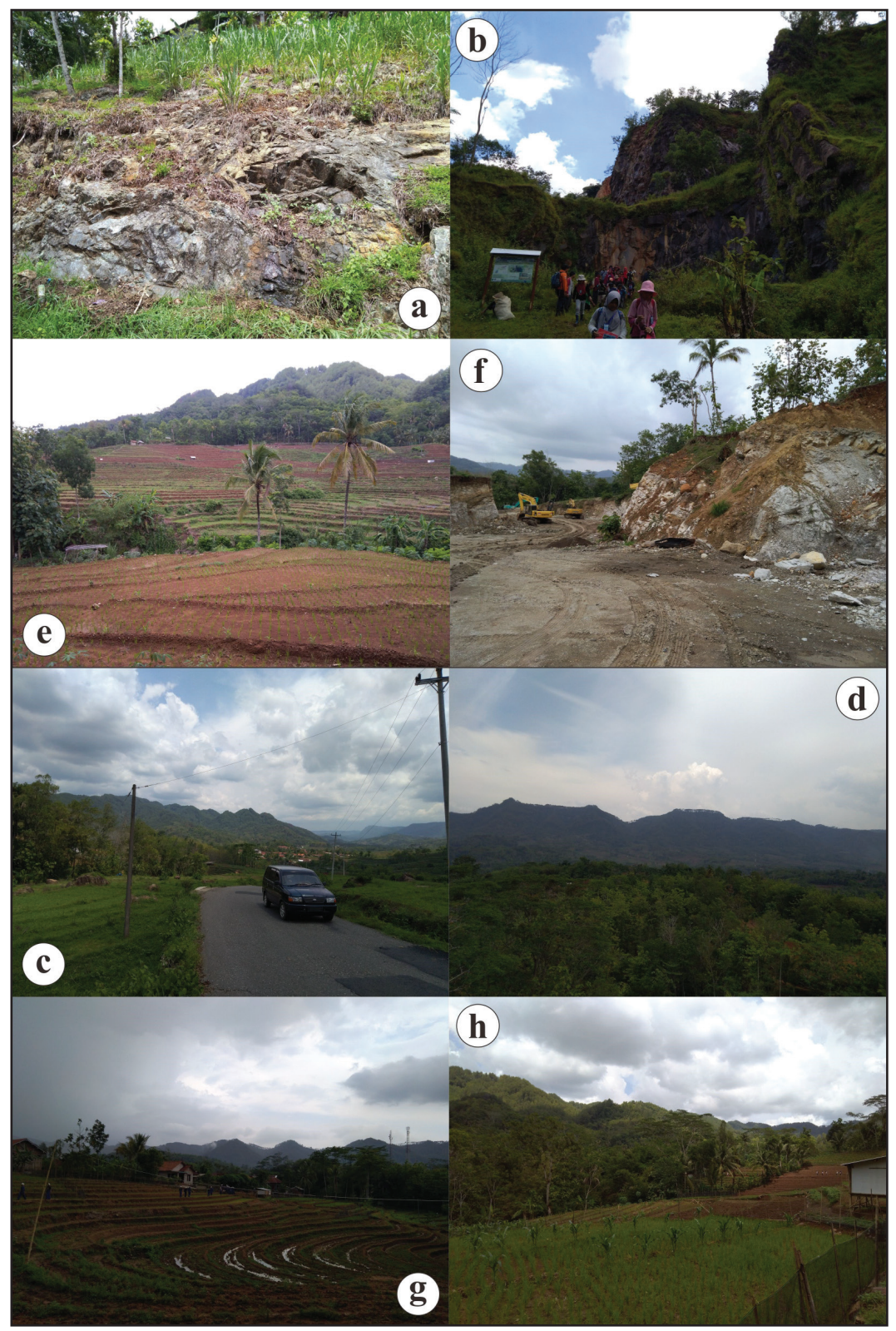

Gambar 3. Gambaran umum dari fisiognomi tanah (a, b), bentukan geomorfologi (c, d), tata guna lahan (e, f), serta kelerengan $(\mathrm{g}, \mathrm{h})$ di daerah Karanggayam dan Karangsambung.

(subsurface). Peningkatan kemampuan infiltrasi hanya terjadi pada $20 \%$ sisa wilayahnya, yang merupakan dataran rendah. Daerah yang datar dengan tingkat kerapatan vegetasi tinggi akan memberikan waktu yang cukup untuk air permukaan masuk ke bawah permukaan dan mengurangi tingkat evaporasi di wilayah tersebut (Raju drr., 2019), dibandingkan daerah dengan elevasi tinggi dan terjal yang membuat air permukaan langsung melimpas (run-off) ke sungai-sungai di sekitarnya.
Lokasi 1-3 didominasi oleh batuan metamorf dan beku, seperti serpentinit, filit, dan diabas, sedangkan di lokasi 4-6 didominasi oleh batuan sedimen, contohnya batugamping numulit, batulempung bersisik, dan batupasir karbonatan (Gambar 2 dan 5). Batuan-batuan tersebut tersingkap ke permukaan karena dikontrol oleh struktur geologi (Gambar 2 dan 8), seperti lipatan dan patahan. Lipatan berupa antiklin dan sinklin dengan dimensi yang sangat luas membentang dari sisi barat Karanggayam hingga 


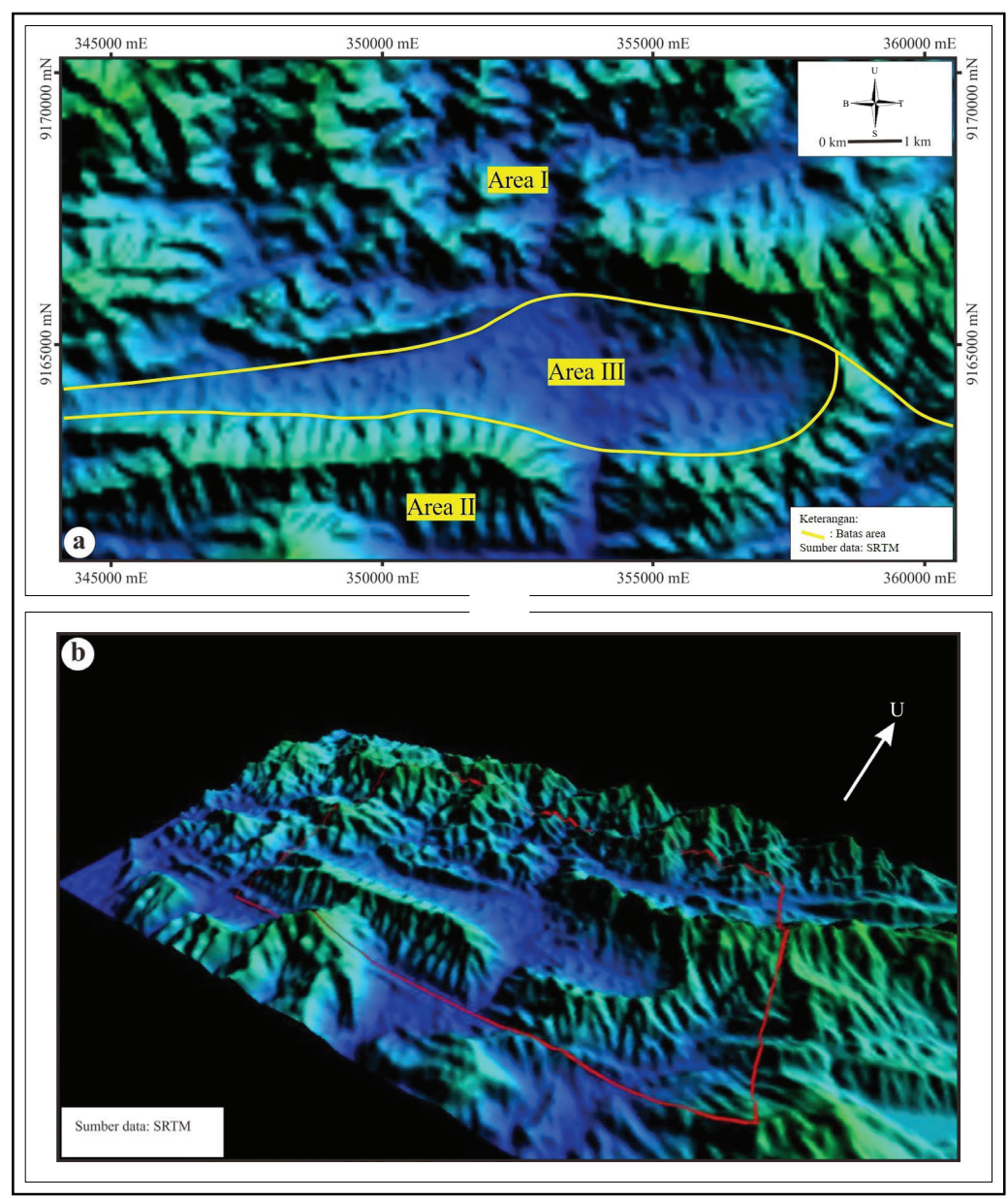

Gambar 4. (a, b) Bentukan geomorfologi di daerah Karanggayam dan Karangsambung (atlas shader). Area I: Perbukitan tinggi dan terjal; area II: Perbukitan rendah dan landai; area III: Dataran rendah.

sisi timur Karangsambung, mengangkat batuanbatuan dasar untuk naik ke permukaan (Wakita drr., 1994). Distribusi batuan-batuan tersebut juga tidak terlepas dari peran patahan seperti sesar naik dan geser yang banyak ditemukan di daerah Karanggayam dan Karangsambung.

Kondisi geologi yang sebagian besar disusun oleh batuan keras membuat kemampuan penyimpanan air tanah di daerah Karanggayam dan Karangsambung menjadi sangat berkurang. Kemampuan penyimpanan tersebut dikontrol oleh dua parameter batuan, yaitu porositas dan permeabilitas (Tabel 2) (Etikala drr., 2019; Raju drr., 2019; Rosari drr., 2017). Batuan beku dan metamorf memiliki porositas primer yang sangat kecil, karena dalam pembentukannya hampir tidak menyisakan ruang antarmineral. Konektivitas antarbutir mineralnya pun hampir tidak ada, sehingga kemampuan batuan tersebut untuk meloloskan air (permeabilitas) juga termasuk sangat buruk. Hal tersebut menyulitkan air permukaan untuk mengalami infiltrasi dan perkolasi menuju akuifer di bawah permukaan (Ebrahim dan Villholth, 2016; Hamdi drr., 2018).

Harapan terbesar air permukaan dapat masuk ke dalam akuifer adalah dengan adanya porositas sekunder, yang pembentukannya dikontrol oleh struktur geologi daerah Karanggayam dan Karangsambung. Porositas tersebut berupa rekahan pada batuan akibat terjadinya lipatan maupun patahan, dan kapasitasnya pun tergolong sangat besar (Ebrahim dan Villholth, 2016; Mahmoud dan Kotb, 2017; Mul drr., 2007). Namun, di sisi lain, rekahan pada batuan yang sangat besar tersebut tidak saling terkoneksi dengan baik, 


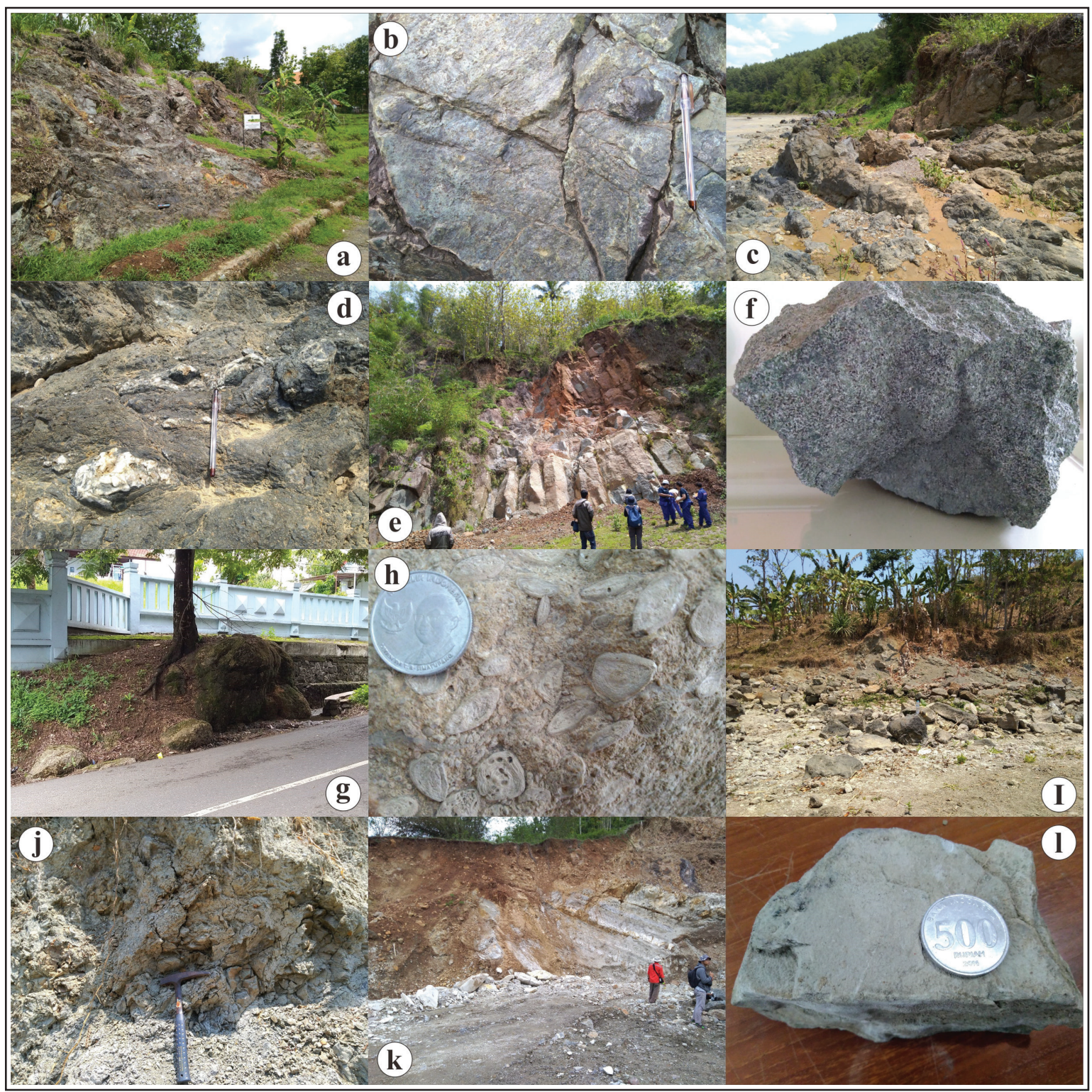

Gambar 5. Percontoh batuan dari setiap titik lokasi. Serpentinit (lokasi 1) berwarna hijau tua, ekuigranular, masif dengan sedikit serat-serat, memiliki kilap minyak, tidak berfoliasi, dan sedikit mengalami alterasi (a, b); filit (lokasi 2) memiliki warna abu-abu gelap, belahan slaty, kilap mika, lepidoblastik, terdapat fragmen-fragmen kuarsa berukuran 5,00-30,00 sentimeter $(\mathrm{cm})$, serta memperlihatkan lipatan-lipatan (microfolds) dan patahan-patahan mikro (microfaults) (c, d); diabas (lokasi 3) memiliki warna abu-abu kehijauan, fanerik, subhedral-hipidiomorfik, ekuigranular, holokristalin, dengan tekstur khusus diabasik (e, f); batugamping numulites (lokasi 4) memiliki warna abu-abu kecokelatan, butir berukuran pasir kasarhalus, berbentuk menyudut-membulat, terpilah buruk, kemas terbuka, semen karbonat, porositas buruk-sedang, kompak, dengan tebal singkapan 0,50-1,70 m, serta terdapat fragmen berupa fosil numulites ( $\mathrm{g}, \mathrm{h}$ ); batulempung bersisik (lokasi 5) berwarna cokelat keputihan, dengan ukuran butir lempung, semen karbonat, rapuh, dan tebal singkapan antara 0,30-1,80 m (i, j); batupasir karbonatan (lokasi 6) memiliki warna abu-abu kecokelatan-keputihan, ukuran butir mulai dari pasir sedanghalus, berbentuk membulat tanggung-membulat, terpilah baik, kemas tertutup, semen karbonat, porositas sedang-baik, kompak, serta tebal singkapan mencapai $\pm 2,80 \mathrm{~m}(\mathrm{k}, \mathrm{l})$.

sehingga permeabilitasnya tergolong sangat buruk. Hal tersebut diakibatkan oleh aktivitas tektonik yang bekerja terlalu intensif, sehingga konektivitas rekahan pada batuan yang sudah terbentuk kembali tertutup oleh terbentuknya rekahan baru pada batuan. Rekahan baru yang terbentuk tersebut pada akhirnya akan membuat keseluruhan konektivitas antarrekahan menjadi rapuh dan mudah hancur (Jenifer dan Jha, 2017; Mahmoud dan Kotb, 2017). 
Tabel 2. Perbandingan umum porositas dan permeabilitas untuk setiap jenis batuan (Etikala drr., 2019; Raju drr., 2019; Rosari drr., 2017).

\begin{tabular}{|c|c|c|c|c|}
\hline No. & $\begin{array}{c}\text { Jenis } \\
\text { Batuan }\end{array}$ & $\begin{array}{l}\text { Nama } \\
\text { Batuan }\end{array}$ & $\begin{array}{c}\text { Porositas } \\
\text { (\%) }\end{array}$ & $\begin{array}{l}\text { Permea- } \\
\text { bilitas }\end{array}$ \\
\hline 1 & Batuan & Basalt & $0-10$ & Buruk \\
\hline 2 & $\begin{array}{l}\text { kristalin (beku/ } \\
\text { metamorf) }\end{array}$ & $\begin{array}{l}\text { Basalt } \\
\text { (fractured) }\end{array}$ & $5-50$ & $\begin{array}{l}\text { Buruk- } \\
\text { sedang }\end{array}$ \\
\hline 3 & $\begin{array}{l}\text { Batuan } \\
\text { sedimen }\end{array}$ & Batupasir & $5-30$ & Baik \\
\hline 4 & Sedimen & Pasir & $25-50$ & $\begin{array}{l}\text { Baik-sangat } \\
\text { baik }\end{array}$ \\
\hline
\end{tabular}

Lahan di daerah Karanggayam dan Karangsambung sebagian besar merupakan wilayah konservasi, dengan luas mencapai $\pm 70 \%$ dari total wilayahnya (Gambar 6). Wilayah konservasi ini ditumbuhi oleh berbagai macam vegetasi dengan ketinggian $\geq 1,00 \mathrm{~m}$, termasuk di dalamnya hutan produksi berupa pohon-pohon pinus yang dikelola oleh Perusahaan Hutan Negara Indonesia (Perhutani). Hutan produksi tersebut secara umum tidak termasuk ke dalam alih fungsi lahan yang berdampak negatif, karena vegetasi yang digunakan memiliki spesifikasi yang tidak jauh berbeda dengan vegetasi aslinya. Penduduk sekitar sebagian besar memanfaatkan sisa 30\% wilayahnya untuk persawahan dan perkebunan, serta oleh beberapa perusahaan sebagai area pertambangan pasir dan batu (Gambar 3.e dan 3.f). Alih fungsi lahan menjadi persawahan dan perkebunan disebabkan oleh suburnya tanah di daerah tersebut, yang merupakan hasil dari pelapukan batuan-batuan dasar dengan banyak kandungan unsur dan mineral yang dibutuhkan oleh tanaman. Di sisi lain, alih fungsi lahan menjadi area pertambangan disebabkan oleh banyaknya batuan keras di daerah tersebut, yang secara umum berguna untuk kebutuhan industri maupun pembangunan skala menengah.

Alih fungsi lahan (khususnya perkebunan dan pertambangan) yang terjadi sebesar $30 \%$ memberikan dampak pada sistem hidrologihidrogeologi regional, sehingga menyebabkan berkurangnya kuantitas air tanah di daerah tersebut. Dampak yang dimaksud adalah hilangnya jalan masuk alamiah (diminishing natural pathway) untuk infiltrasi air permukaan masuk ke dalam tanah, serta perubahan siklus aliran sungai dan area cadangan air tanah (Etikala drr., 2019; Mul drr., 2007). Namun, di sisi lain, alih fungsi lahan menjadi persawahan dapat sedikit membantu proses infiltrasi air permukaan, karena kuantitas dan kualitas porositas tanah menjadi semakin banyak dan besar. Tata guna lahan di daerah Karanggayam dan Karangsambung secara keseluruhan masih tergolong baik, karena terjadinya alih fungsi lahan masih diimbangi oleh adanya wilayah konservasi yang sangat luas.

Secara umum daerah Karanggayam dan Karangsambung memiliki iklim yang normal, dengan durasi musim hujan dan kemarau masing-masing selama enam bulan (Saputro dan Mulyasari, 2020). Musim hujan dimulai

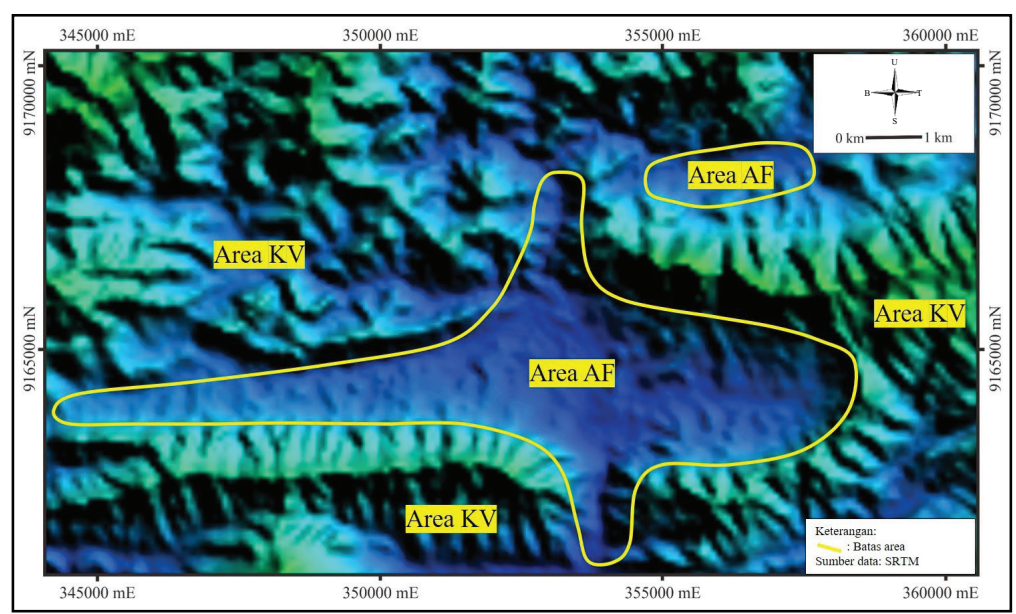

Gambar 6. Tata guna lahan di daerah Karanggayam dan Karangsambung (atlas shader). Area KV: Area konservasi; area AF: Area alih fungsi lahan. 
sekitar Oktober hingga Maret, yang kemudian dilanjutkan musim kemarau dari April hingga September (Tabel 3). Frekuensi terjadinya hujan pada musimnya hampir setiap hari dalam satu minggu, dengan durasi \pm 3 jam/hari. Frekuensi tersebut berbanding terbalik saat musim kemarau, yang maksimal hanya terjadi tiga kali dalam satu bulan dengan durasi masing-masing $\pm 3 / 4 \mathrm{jam}$. Distribusi turunnya hujan juga cukup luas dan merata, dari wilayah perbukitan hingga dataran mendapatkan frekuensi dan durasi yang sama.

Tabel 3. Data curah hujan dan hari hujan di Kabupaten Kebumen (Badan Pusat Statistik, 2021).

\begin{tabular}{clcc}
\hline & & \multicolumn{2}{c}{ Tahun 2018 } \\
\cline { 3 - 4 } No. & Bulan & $\begin{array}{c}\text { Curah Hujan } \\
\text { (mm) }\end{array}$ & $\begin{array}{c}\text { Hari Hujan } \\
\text { (hari) }\end{array}$ \\
\hline 1 & Januari & 465 & 26 \\
2 & Februari & 407 & 22 \\
3 & Maret & 513 & 18 \\
4 & April & 433 & 15 \\
5 & Mei & 105 & 4 \\
6 & Juni & 18 & 3 \\
7 & Juli & 5 & 1 \\
8 & Agustus & 10 & 3 \\
9 & September & 35 & 7 \\
10 & Oktober & 23 & 8 \\
11 & November & 667 & 20 \\
12 & Desember & 441 & 22 \\
& Tahunan & 3122 & 149 \\
\hline
\end{tabular}

Frekuensi, durasi, serta distribusi yang sama dan merata tersebut ternyata tidak memberikan dampak yang signifikan terhadap kenaikan muka air tanah, justru sebaliknya muka air sungai yang mengalami kenaikan tajam baik dalam hal ketinggian maupun volumenya. Densitas drainase dan frekuensi aliran yang tinggi dicurigai menjadi penyebab terjadinya hal tersebut. Angka infiltrasi merupakan hasil perkalian antara densitas drainase dan frekuensi aliran (Mishra drr., 2019), sehingga artinya nilai dari angka infiltrasinya juga tinggi. Angka tersebut mencerminkan bahwa limpasan air dari perbukitan maupun dataran ke sungai sangat tinggi (Pophare dan Balpande, 2014; Watson drr., 2018). Limpasan air yang tinggi menandakan kapasitas perkolasi yang terjadi di bawah permukaan sangat rendah, sehingga cadangan air tanah yang tersimpan juga sangat sedikit. Hal tersebut didukung dengan data kondisi geologi daerah penelitian yang tersusun oleh batuan kristalin dan batuan sedimen, yang umumnya memiliki persentase porositas rendah-menengah dan tingkat permeabilitas buruk-baik (Tabel 2).

Pengukuran langsung di lapangan menunjukkan kelerengan daerah Karanggayam dan Karangsambung terbagi menjadi tiga tingkat kemiringan (Gambar 2), yaitu curam $\left(\geq 45^{\circ}\right)$, menengah $\left(45^{\circ}-25^{\circ}\right)$, dan landai $\left(<25^{\circ}\right)$, dengan luas area masing-masing $50 \%, 30 \%$, dan $20 \%$ dari total luas daerah Karanggayam dan Karangsambung (Gambar 3.g dan 3.h). Tingkat kemiringan tersebut mencerminkan pengaruh langsung kelerengan terhadap proses infiltrasi air permukaan (Raju drr., 2019). Lereng dengan kemiringan curam terdapat pada bagian puncak dari antiklin yang mengalami erosi dan sejumlah bukit-bukit kompleks batuan dasar samudra, sedangkan sayap-sayap antiklin memiliki kemiringan menengah-landai (Gambar 7). Lereng yang curam tersebut meningkatkan jumlah aliran permukaan langsung menuju sungai, dibandingkan jumlah infiltrasi dan perkolasi ke akuifer (Ebrahim dan Villholth, 2016; Singh drr., 2019). Hal ini juga menjelaskan bahwa cadangan air tanah pada lereng menengah-landai jauh lebih terjaga kuantitasnya dibandingkan lereng yang curam (Etikala drr., 2019).

Kelerengan dengan kemiringan curam seluas $50 \%$ dari total luas daerah Karanggayam dan Karangsambung tidak serta-merta meningkatkan jumlah aliran permukaan langsung menuju sungai (Gambar 7). Adanya penghalang menyebabkan terjadinya pengurangan kecepatan aliran (Gambar 3.c dan 3.d), sehingga air permukaan mempunyai waktu yang cukup untuk mengalami infiltrasi (Gambar 4). Penghalang tersebut terbagi menjadi dua jenis, yaitu penghalang positif dan negatif (Hallema drr., 2016). Penghalang positif umumnya berupa gundukan yang menonjol di atas permukaan, sedangkan penghalang negatif berupa cekungan yang membentuk lajur ataupun cekungan yang tertutup (Hallema drr., 2016; Mishra drr., 2019). Kedua jenis penghalang ini memiliki fungsi yang sama 


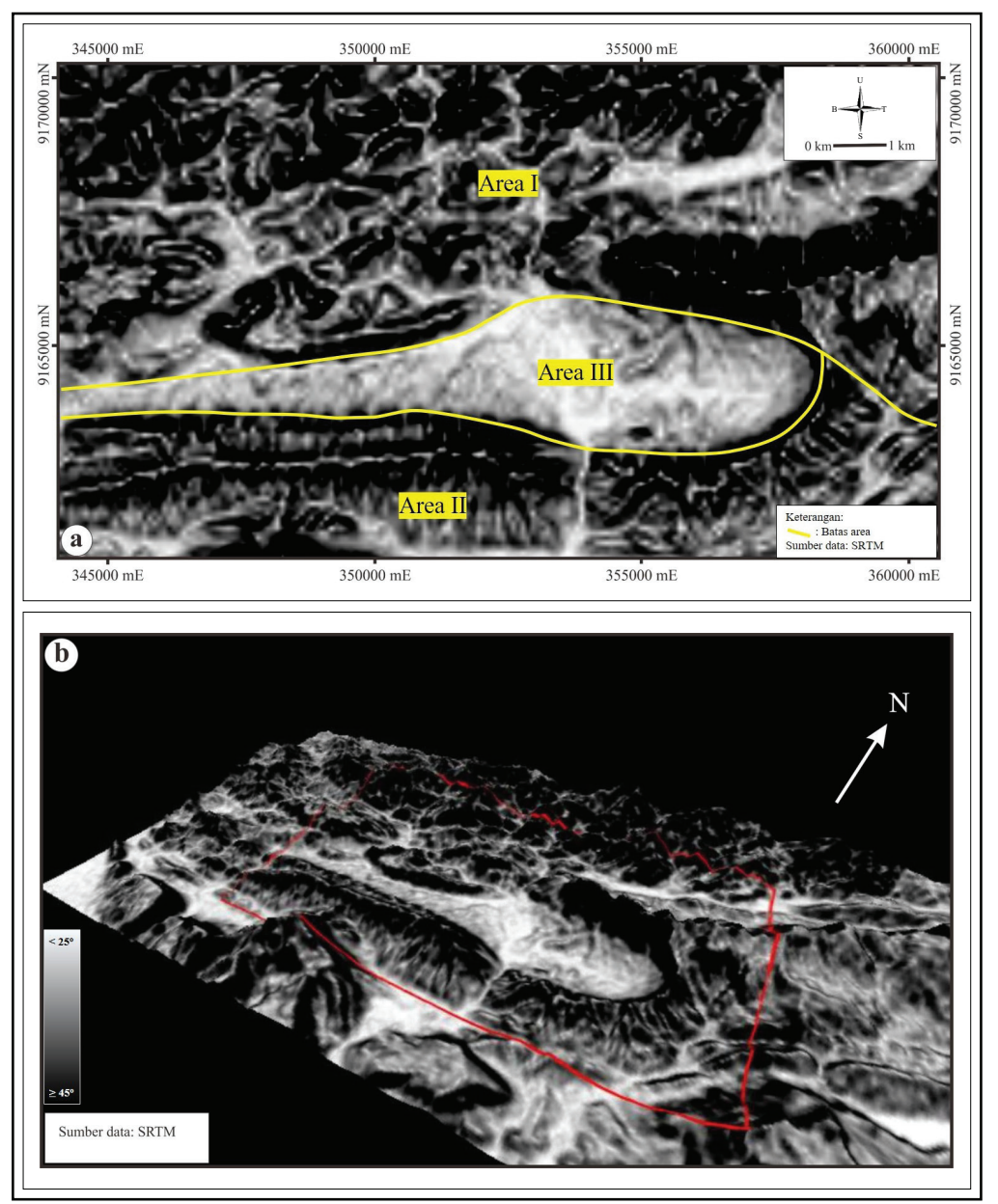

Gambar 7. (a, b) Kelerengan di daerah Karanggayam dan Karangsambung (slope shader). Area I: Tingkat kemiringan curam; area II: Tingkat kemiringan menengah; area III: Tingkat kemiringan landai.

untuk mengurangi kecepatan aliran, tetapi dengan cara kerja yang berbeda.

Penghalang positif mengurangi kecepatan aliran dengan cara membagi atau membelah aliran menjadi dua bagian. Pembagian tersebut membuat volume aliran yang besar terbagi menjadi lebih kecil, sehingga secara otomatis kecepatan aliran akan melambat akibat gravitasi massa yang berkurang. Penghalang positif ini banyak ditemukan pada lereng bukit-bukit kompleks batuan dasar samudra seperti di lokasi 1 dan 2 , serta sayap-sayap antiklin seperti di lokasi 6 (Gambar 2 dan 4). Di sisi lain, penghalang negatif justru mengurangi kecepatan aliran dengan cara menyatukan beberapa aliran ke dalam satu cekungan. Hal ini menyebabkan sebagian besar volume aliran akan tertahan dalam waktu yang lama dan akhirnya mengalami infiltrasi.
Contoh penghalang negatif banyak ditemukan pada lereng lembah antiklin bagian utara seperti di lokasi 3, dan selatan seperti di lokasi 5 (Gambar 2 dan 4). Penghalang positif maupun negatif dinilai memiliki kontribusi positif dalam hal pengisian cadangan air tanah di daerah Karanggayam dan Karangsambung.

Potensi cadangan air tanah pada suatu wilayah akan semakin bagus jika nilai densitas kelurusannya semakin tinggi (Etikala drr., 2019; Mishra drr., 2019). Nilai tersebut (Ld) didapatkan dari hasil perbandingan antara jumlah seluruh panjang kelurusan (Li) dengan luas area (A) dalam satuan kilometer persegi $\left(\mathrm{km}^{2}\right)$ (1) (Etikala drr., 2019).

$$
L d=\sum_{i=1}^{n} L i / A\left(\mathrm{~km}^{2}\right)
$$


Kelurusan merupakan suatu pola berupa garis linear dan kontinu yang merepresentasikan kondisi faktual dari permukaan atau bawah permukaan bumi, baik secara stratigrafi, struktur geologi, maupun geofisika (Mishra drr., 2019). Kelurusan di daerah Karanggayam dan Karangsambung sebagian besar terbentuk akibat adanya aktivitas tektonik yang sangat intensif. Raju drr. (2019) menyatakan bahwa maksud dari intensifnya aktivitas tektonik tersebut tidak hanya berupa tektonik skala besar, tetapi dapat pula berupa patahan-patahan aktif yang bersifat lokal (Gambar 2). Pengukuran densitas kelurusan yang dilakukan di daerah Karanggayam dan Karangsambung menghasilkan nilai antara 0,00 $1,16 \mathrm{~km} / \mathrm{km}^{2}$, dengan rincian jumlah panjang kelurusan 181,83 km dan luas area 156,66 km² (1). Kelurusan-kelurusan tersebut memperlihatkan kecenderungan semakin ke arah selatan nilai densitasnya semakin tinggi, diperkirakan karena adanya lipatan berupa antiklin dan sinklin di sekitar wilayah tersebut (Gambar 8). Nilai densitas kelurusan yang tergolong menengah-tinggi tersebut menunjukkan bahwa daerah Karanggayam dan Karangsambung seharusnya terhindar dari kemungkinan bencana kekeringan, karena memiliki probabilitas potensi cadangan air tanah yang bagus.

Area yang masih memiliki cadangan air tanah di daerah Karanggayam dan Karangsambung berada di sekitar lembah antiklin dan lereng sayap antiklin bagian selatan-tenggara (S-SE) (Gambar 9 dan 10), secara umum termasuk dalam zona akuifer dengan produktivitas kecilsedang (ESDM One Map, 2021). Area tersebut memiliki dimensi horizontal yang memanjang barat-timur (W-E), sesuai hasil pengukuran arah kemenerusan batuan di sekitar lokasi 5 dan 6 (Tabel 4). Luas area tersebut sekitar 11\% dari luas daerah Karanggayam dan Karangsambung secara keseluruhan $\left( \pm 17,19 \mathrm{~km}^{2}\right)$, dan merupakan bagian dari Formasi Karangsambung (Eosen-Oligosen) dan Penosogan (Miosen).

Delineasi area tersebut ditentukan berdasarkan hasil integrasi seluruh data karakteristik geografi dan geomorfologi yang telah dilakukan sebelumnya. Morfologi berupa dataran rendah dengan vegetasi yang rapat dan tinggi (Gambar 3.c dan 3.d), serta lereng dengan kemiringan menengah-landai (Gambar 3.g dan 3.h) membuat area tersebut sangat mendukung proses infiltrasi dapat berjalan dengan sempurna.

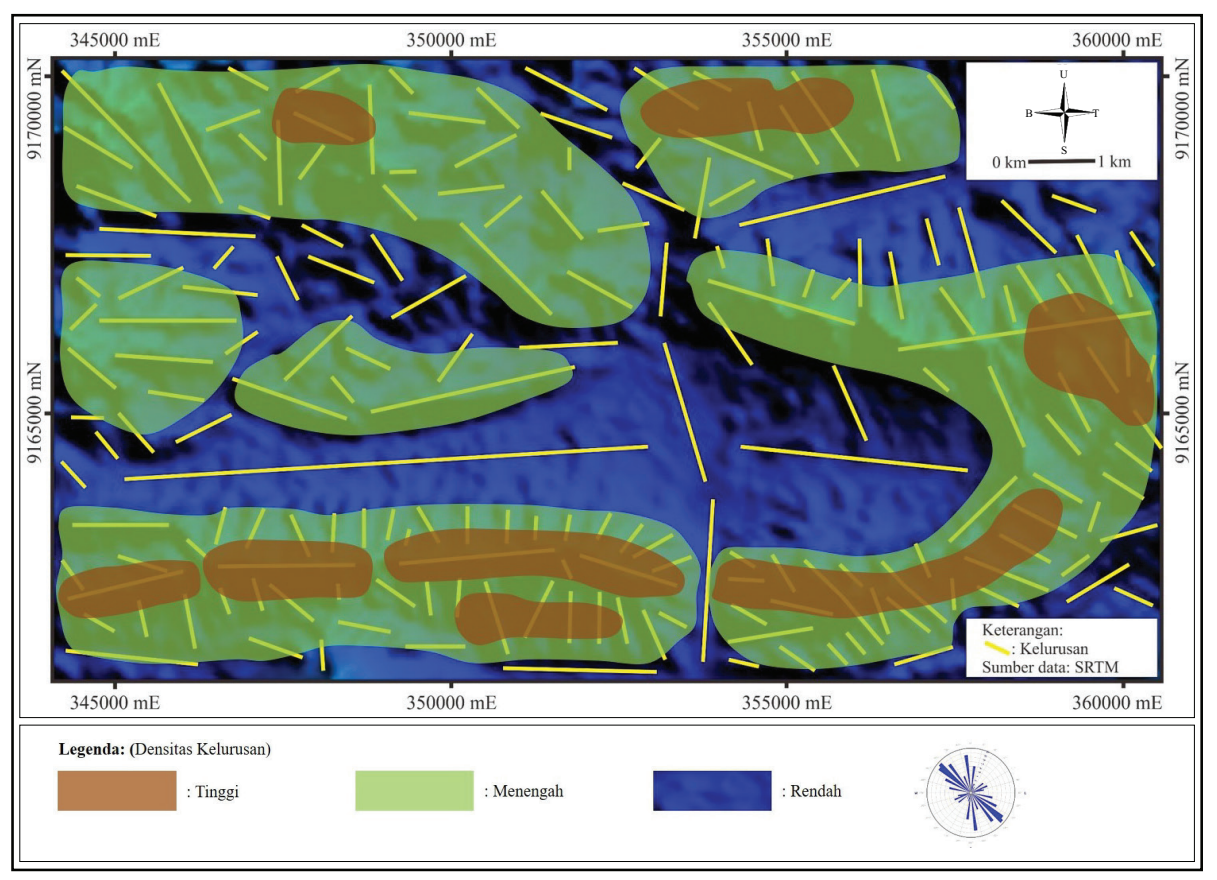

Gambar 8. Densitas kelurusan di daerah Karanggayam dan Karangsambung. 


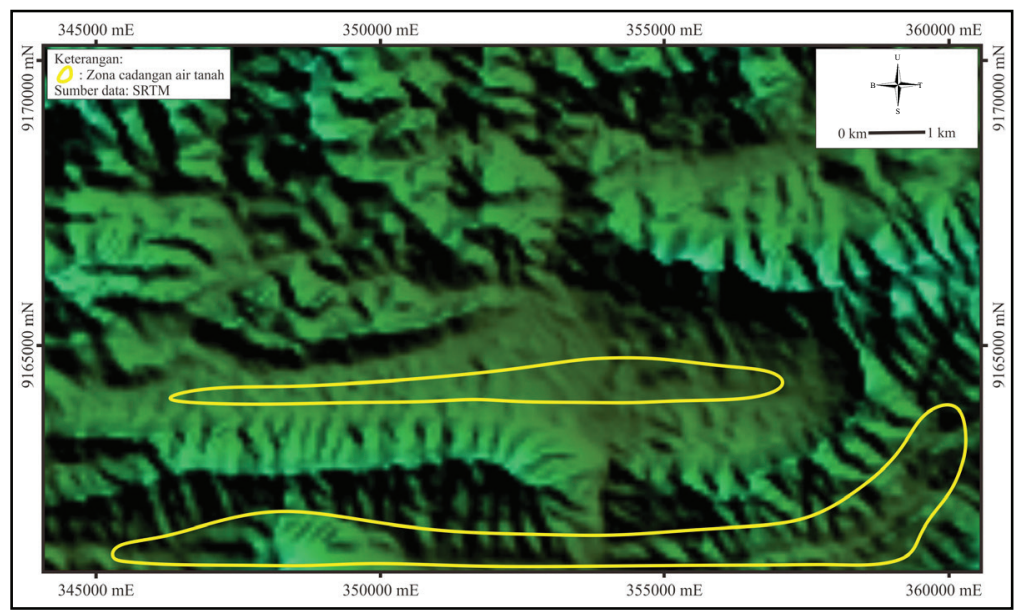

Gambar 9. Zona probabilitas potensi cadangan air tanah di daerah Karanggayam dan Karangsambung.

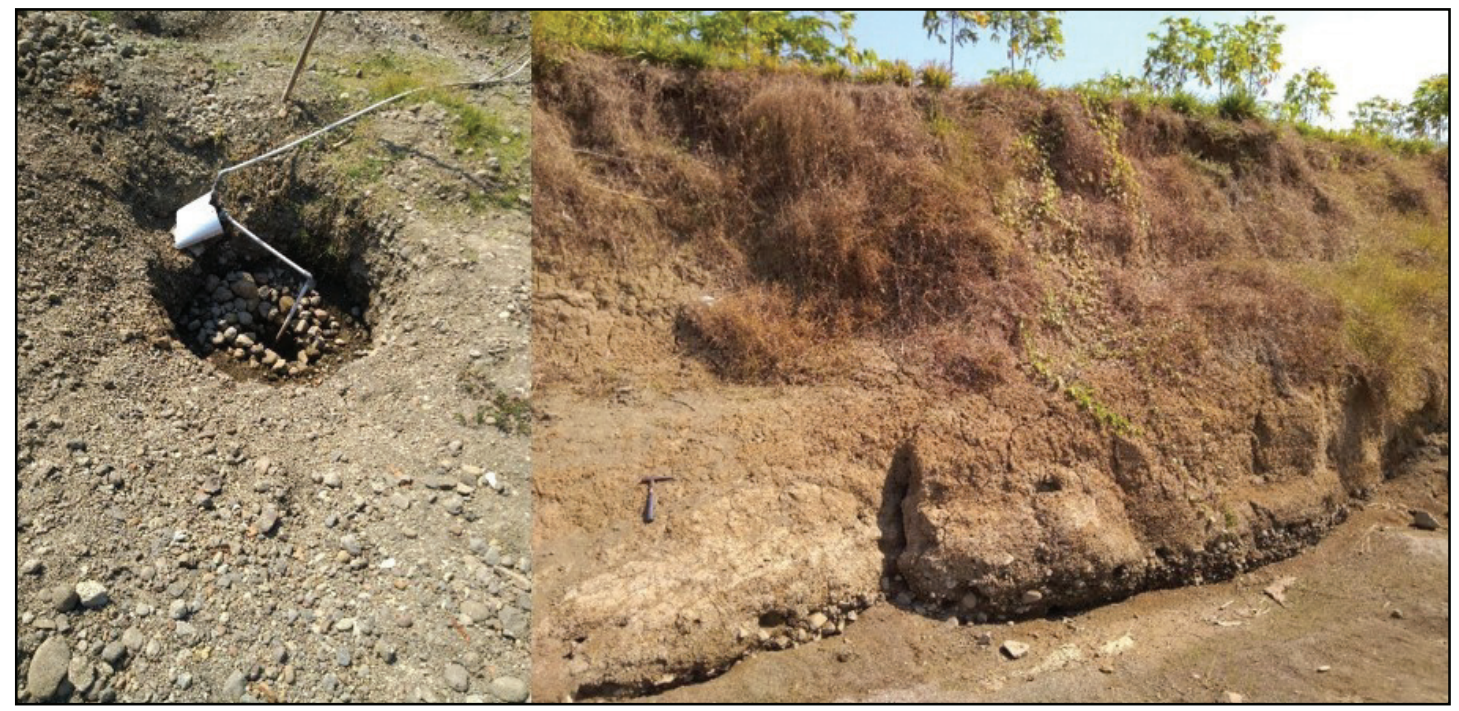

Gambar 10. Pengeboran dangkal pada cabang/anak sungai dan ketebalan tanah di sekitar zona probabilitas potensi cadangan air tanah.

Tabel 4. Hasil pengukuran arah kemenerusan dan kemiringan batuan.

\begin{tabular}{ccc}
\hline \multirow{2}{*}{ No. } & \multicolumn{2}{c}{ Strike/Dip } \\
\cline { 2 - 3 } & Lokasi 5 & Lokasi 6 \\
\hline 1 & $\mathrm{~N} 281^{\circ} \mathrm{E} / 25^{\circ}$ & $\mathrm{N} 83^{\circ} \mathrm{E} / 17^{\circ}$ \\
2 & $\mathrm{~N} 276^{\circ} \mathrm{E} / 27^{\circ}$ & $\mathrm{N} 97^{\circ} \mathrm{E} / 19^{\circ}$ \\
3 & $\mathrm{~N} 272^{\circ} \mathrm{E} / 23^{\circ}$ & $\mathrm{N} 88^{\circ} \mathrm{E} / 23^{\circ}$ \\
4 & $\mathrm{~N} 263^{\circ} \mathrm{E} / 18^{\circ}$ & $\mathrm{N} 101^{\circ} \mathrm{E} / 20^{\circ}$ \\
5 & $\mathrm{~N} 266^{\circ} \mathrm{E} / 26^{\circ}$ & $\mathrm{N} 94^{\circ} \mathrm{E} / 26^{\circ}$ \\
\hline
\end{tabular}

Gundukan maupun cekungan (Gambar 4) yang banyak terdapat di sisi lereng juga sangat membantu dalam mengontrol kecepatan aliran, sehingga air yang mengalami infiltrasi jumlahnya akan tetap lebih banyak dibandingkan yang langsung limpas ke sungai. Area tersebut juga termasuk ke dalam wilayah konservasi di daerah Karanggayam dan Karangsambung, sehingga sangat kecil kemungkinan terjadinya perubahan lingkungan yang disebabkan oleh manusia. Hal tersebut juga didukung oleh nilai densitas kelurusan yang tergolong menengah-tinggi (1), memungkinkan area tersebut (Gambar 9) memiliki porositas dan permeabilitas sekunder yang bagus sehingga tingkat probabilitas potensi cadangan air tanahnya meningkat.

Arah aliran air yang secara umum mengikuti arah kemiringan batuan dan lereng dapat mengindikasikan lereng sayap antiklin bagian 
utara $(\mathrm{N})$ juga memiliki potensi sebagai area cadangan air tanah. Namun, hasil integrasi seluruh data karakteristik geografi dan geomorfologi tidak memungkinkan terjadinya hal tersebut. Salah satu yang sangat signifikan perbedaannya adalah kondisi geologi yang langsung dibatasi oleh batuan-batuan keras dari Kompleks Lok Ulo (Gambar 2), sehingga menyebabkan air perlahan-lahan akan tetap mengalami evaporasi ataupun limpas ke sungai.

\section{KESIMPULAN}

Bencana kekeringan yang terjadi di daerah Karanggayam dan Karangsambung dikontrol oleh delapan karakteristik geografi dan geomorfologi (Mishra drr., 2019; Saputro dan Mulyasari, 2020). Karakteristik yang paling bertanggung jawab adalah fisiognomi tanah, kondisi geologi, dan angka infiltrasi. Ketiga karakteristik tersebut berada pada tingkat yang sangat buruk, sehingga mampu membuat kebutuhan dan aktivitas masyarakat sekitar terkait air tanah menjadi sangat terganggu khususnya pada musim kemarau. Porositas-permeabilitas tanah dan batuan yang buruk, serta densitas drainase dan frekuensi aliran yang tinggi menjadi penyebab utama fisiognomi tanah, kondisi geologi, dan angka infiltrasi berada pada tingkat tersebut.

Ketahanan daerah Karanggayam dan Karangsambung terhadap dampak bencana kekeringan terletak pada area di sekitar lembah antiklin dan lereng sayap antiklin bagian selatantenggara. Area tersebut memanjang dari barat Karanggayam hingga timur Karangsambung dengan dimensi horizontal (Gambar 9), yang merupakan lokasi potensial untuk ditemukannya cadangan air tanah. Khusus area di sekitar lembah antiklin, untuk mendapatkan air tersebut dapat dengan melakukan pengeboran dangkal pada cabang/anak sungainya (Gambar 10). Hasil pelapukan batuan dan erosi akibat seringnya kontak dengan air sungai selama musim hujan, membuat area tersebut memiliki batuan dengan porositas cukup baik dan tanah yang cukup tebal $( \pm 3-10 \mathrm{~m})$ sebagai tempat penyimpan air. Cadangan air tanah yang berada di sekitar lembah antiklin dan lereng sayap antiklin bagian selatan-tenggara diharapkan mampu memenuhi kebutuhan dan aktivitas masyarakat sekitar secara total, karena berdasarkan hasil integrasi seluruh data yang telah dilakukan sebelumnya, diketahui bahwa area tersebut memiliki tingkat probabilitas potensi cadangan air tanah yang tinggi.

Seluruh hasil evaluasi tersebut juga berguna bagi pemerintah daerah dan badan pengelola taman bumi dalam melakukan perencanaan lingkungan serta kebijakan manajemen yang efektif dan berkelanjutan mengenai sumber daya air tanah, perencanaan mitigasi bencana geologi, serta perencanaan tata guna lahan agar keberadaan taman bumi dapat memberikan manfaat maksimal untuk seluruh masyarakat sekitar daerah Karanggayam dan Karangsambung.

\section{UCAPAN TERIMA KASIH}

Terima kasih kepada rekan-rekan di Unila Lampung atas telaah, ulasan, dan masukannya yang membangun, serta Badan Penanggulangan Bencana Daerah (BPBD) yang telah memberikan tambahan data untuk melengkapi kebutuhan analisis penelitian ini.

\section{DAFTAR PUSTAKA}

Asikin, S., Handoyo, A., Busono, H., dan Gafoer, S., 1992. Peta Geologi Bersistem, Lembar Kebumen, Jawa, Skala 1:100.000. Pusat Penelitian dan Pengembangan Geologi, Bandung.

Badan Pusat Statistik., 2021. Hari Hujan dan Curah Hujan. Badan Pusat Statistik (BPS), Kebumen. https://kebumenkab.bps.go.id/ indicator/151/56/1/hari-hujan-dan-curahhujan.html

Ebrahim, G. Y., dan Villholth, K. G., 2016. Estimating shallow groundwater availability in small catchments using streamflow recession and instream flow requirements of rivers in South Africa. Journal of Hydrol- 
ogy, 541, 754-765. https://doi.org/10.1016/j. jhydrol.2016.07.032

ESDM One Map., 2021. Peta Produktivitas Akuifer. Kementerian Energi dan Sumber Daya Mineral. https://geoportal.esdm.go.id/ geologi/

Etikala, B., Golla, V., Li, P., dan Renati, S., 2019. Deciphering groundwater potential zones using MIF technique and GIS: A study from Tirupati Area, Chittoor District, Andhra Pradesh, India. HydroResearch, 1, 1-7. https://doi.org/10.1016/j. hydres.2019.04.001

Hallema, D. W., Moussa, R., Sun, G., dan McNulty, S. G., 2016. Surface storm flow prediction on hillslopes based on topography and hydrologic connectivity. Ecological Processes, 5(1), 13. https://doi.org/10.1186/ s13717-016-0057-1

Hamdi, M., Zagrarni, M. F., Djamai, N., Jerbi, H., Goita, K., dan Tarhouni, J., 2018. 3D geological modeling for complex aquifer system conception and groundwater storage assessment: Case of Sisseb El Alem Nadhour Saouaf Basin, northeastern Tunisia. Journal of African Earth Sciences, 143, 178-186. https://doi.org/10.1016/j. jafrearsci.2018.03.017

Han, Z., Huang, S., Huang, Q., Leng, G., Wang, H., Bai, Q., Zhao, J., Ma, L., Wang, L., dan Du, M., 2019. Propagation dynamics from meteorological to groundwater drought and their possible influence factors. Journal of Hydrology, 578(August), 124102. https:// doi.org/10.1016/j.jhydrol.2019.124102

Hao, Z., Hao, F., Singh, V. P., Sun, A. Y., dan Xia, Y., 2016. Probabilistic prediction of hydrologic drought using a conditional probability approach based on the metaGaussian model. Journal of Hydrology, 542, 772-780. https://doi.org/10.1016/j. jhydrol.2016.09.048

Hoque, M. A.-A., Pradhan, B., dan Ahmed, N., 2020. Assessing drought vulnerability using geospatial techniques in northwestern part of Bangladesh. Science of The Total Environ- ment, 705, 135957. https://doi.org/10.1016/j. scitotenv.2019.135957

Hund, S. V., Allen, D. M., Morillas, L., dan Johnson, M. S., 2018. Groundwater recharge indicator as tool for decision makers to increase socio-hydrological resilience to seasonal drought. Journal of Hydrology, 563(May), 1119-1134. https://doi.org/10.1016/j.jhydrol.2018.05.069

Jenifer, M. A., dan Jha, M. K., 2017. Comparison of Analytic Hierarchy Process, Catastrophe and Entropy Techniques for evaluating groundwater prospect of hard-rock aquifer systems. Journal of Hydrology, 548(October 2008), 605-624. https://doi.org/10.1016/j. jhydrol.2017.03.023

Liu, C., Yin, G., Li, M., Shang, D., Deng, B., dan Song, Z., 2019. Deformation and permeability evolution of coals considering the effect of beddings. International Journal of Rock Mechanics and Mining Sciences, 117(March), 49-62. https://doi. org/10.1016/j.ijrmms.2019.03.016

Mahmoud, H. H., dan Kotb, A. D. M., 2017. Impact of the geological structures on the groundwater potential using geophysical techniques in West Bani Mazar Area, El Minia - western desert, Egypt. Journal of African Earth Sciences, 130, 161-173. https:// doi.org/10.1016/j.jafrearsci.2017.03.024

Mao, Y., Wu, Z., He, H., Lu, G., Xu, H., dan Lin, Q., 2017. Spatio-temporal analysis of drought in a typical plain region based on the soil moisture anomaly percentage index. Science of The Total Environment, 576, 752-765. https://doi.org/10.1016/j. scitotenv.2016.10.116

Mishra, A. K., Upadhyay, A., Srivastava, A., dan Rai, S. C., 2019. Probabilistic groundwater recharge zonation in hard rock terrain using geospatial techniques in Veniar Watershed, South India. Ecohydrology \& Hydrobiology, February 2019. https://doi.org/10.1016/j. ecohyd.2019.01.004

Mul, M. L., Mutiibwa, R. K., Foppen, J. W. A., Uhlenbrook, S., dan Savenije, H. H. 
G., 2007. Identification of groundwater flow systems using geological mapping and chemical spring analysis in South Pare Mountains, Tanzania. Physics and Chemistry of the Earth, Parts $A / B / C, 32(15-18)$, 1015-1022. https://doi.org/10.1016/j. pce.2007.07.004

Pavlova, I., Makarigakis, A., Depret, T., dan Jomelli, V., 2017. Global overview of the geological hazard exposure and disaster risk awareness at world heritage sites. Journal of Cultural Heritage, 28, 151-157. https://doi. org/10.1016/j.culher.2015.11.001

Pophare, A. M., dan Balpande, U. S., 2014. Morphometric analysis of Suketi River Basin, Himachal Himalaya, India. Journal of Earth System Science, 123(7), 1501-1515. https://doi.org/10.1007/s12040-014-0487-z

Raju, R. S., Raju, G. S., dan Rajasekhar, M., 2019. Identification of groundwater potential zones in Mandavi River Basin, Andhra Pradesh, India using remote sensing, GIS and MIF techniques. HydroResearch, 2, 1-11. https://doi.org/10.1016/j.hydres.2019.09.001

Rosari, A. A., Muris, dan Arsyad, M., 2017. Analisis sifat fisis dan sifat mekanik batuan karst Maros. Jurnal Sains dan Pendidikan Fisika (JSPF), 13(3), 276-281.

Saputro, S. P., dan Mulyasari, R., 2020. Aspect and Criteria of Geological Conditions for Groundwater Quantity Control. In S. Savetlana, I. Sukmana, M. A. Muhammad, \& A.
Yudamson (Eds.), Ilmu-Ilmu Teknik Kebencanaan 2019 (1st ed., pp. 148-158). UPT Perpustakaan Universitas Lampung.

Singh, S. K., Zeddies, M., Shankar, U., dan Griffiths, G. A., 2019. Potential groundwater recharge zones within New Zealand. Geoscience Frontiers, 10(3), 1065-1072. https:// doi.org/10.1016/j.gsf.2018.05.018

van Loon, A. F., dan Laaha, G., 2015. Hydrological drought severity explained by climate and catchment characteristics. Journal of Hydrology, 526, 3-14. https://doi.org/10.1016/j. jhydrol.2014.10.059

Wakita, K., Munasri, dan Bambang, W., 1994. Cretaceous radiolarians from the Luk-Ulo Melange Complex in the Karangsambung Area, Central Java, Indonesia. Journal of Southeast Asian Earth Sciences, 9(12), 29-43. https://doi.org/10.1016/07439547(94)90063-9

Watson, A., Miller, J., Fleischer, M., dan de Clercq, W., 2018. Estimation of groundwater recharge via percolation outputs from a rainfall/runoff model for the Verlorenvlei estuarine system, West Coast, South Africa. Journal of Hydrology, 558, 238-254. https:// doi.org/10.1016/j.jhydrol.2018.01.028

Yang, G., Shao, W., Wang, H., dan Han, D., 2016. Drought evolution characteristics and attribution analysis in Northeast China. Procedia Engineering, 154(5), 749-756. https:// doi.org/10.1016/j.proeng.2016.07.579 